\title{
Genetic resources of flax (Linum usitatissimum L.) as very rich source of $\alpha$-linolenic acid
}

\author{
GRAŻYNA SILSKA
}

Institute of Natural Fibres and Medicinal Plants

Wojska Polskiego 71B

60-630 Poznań, Poland

phone +48 61 8455838, e-mail: grazyna.silska@iwnirz.pl

\section{Summary}

Introduction: Polish oilseed and flaxseed collection is a source of genotypes containing very high amounts of $\alpha$-linolenic acid.

Objective: The objective of the study is to test the seeds for the fat content and fatty acids composition in the oil pressed from the 9 tested accessions of flax (Linum usitatissimum L.). Our goal is to promote the Polish flax collection, which seeds are unique as one of the richest sources of $\alpha$-linolenic acid.

Methods: Assays to determine the content of fat and fatty acids composition in linseed oil were performed at the IHAR-PIB Biochemical Laboratory in Poznań. The fat content was determined by infrared analysis (calibration performed on the basis of seed sample at IHAR-PIB in Poznań) by means of a NIRS 6500 spectrophotometer with a reflection detector within the range of 400-2500 $\mathrm{nm}$. The composition of fatty acids was determined by means of a method proposed by Byczyńska and Krzymański (1969), based on gas chromatography of methyl esters of fatty acids contained in linseed oil. The following varieties of flax were investigated: Tabare (INF00111), Szegedi 30 (INF00427), Olin (INF 00444), Redwood 65 (INF00523), Dufferin (INF00540), AC Mc Duff (INF00648), Alfonso Inta (INF00683), Olinette (INF00687), Royale (INF00689).

Results: The content of $\alpha$-linolenic acid (ALA, $\mathrm{C}_{18: 3}$ ) in evaluated genotypes of flax ranged from 48.9 (Royale) to 59.9\% (Alfonso Inta). Content of linoleic acid (LA, $\mathrm{C}_{18: 2}$ ) in evaluated genotypes of flax ranged from 12.4 (Tabare) to $17.1 \%$ (AC Mc Duff). The content of oleic acid (OA, $\mathrm{C}_{18: 1}$ ) of 9 accession of flax ranged from 17.1 (Alfonso Inta) to $26.7 \%$ (Royale). The content of stearic acid in evaluated genotypes of flax ranged from 2.3 (Alfonso Inta) to 5.0\% (Tabare, Szegedi 30) and the content of palmitic acid ranged from 4.7 (Dufferin) to $6.0 \%$ (Olin). The content of fat ranged from 42.7 (Olin) to $52.0 \%$ (AC Mc Duff). The fatty acid ratio n-6/n-3 ranged from $0.23 / 1$ (Tabare) to $0.32 / 1$ (AC Mc Duff).

Key words: flax, Linum usitatissimum, fatty acids, omega-3, flax seeds 


\section{INTRODUCTION}

Institute of Natural Fibres and Medicinal Plants (INF\&MP) is one of the contractors in a longterm project coordinated by Plant Breeding and Acclimatization Institute (IHAR). The aim of this work is to gather and evaluate the Polish Flax Collection (Linum usitatissimum L.), according to morphological traits, biological features and economical traits. The INF\&MP is involved in the development of International Flax Database (IFDB), based on the descriptors adopted by the European Cooperation Programme for Crop Genetic Resources Networks (ECP/GR) for Plant Genetic Resources for Textile Crops Working Group [1]. The agricultural traits of a great importance is to describe the collection of flax in terms of fat content and fatty acids content, because flax seeds accessions of Polish Flax Collection is characterized by a very high content of $\alpha$-linolenic (ALA, $\mathrm{C}_{18: 3}$ ) fatty acids.

Monounsaturated and polyunsaturated fatty acids belong to the group unsaturated fatty acids. Oleic acid $\left(\mathrm{OA}, \mathrm{C}_{18: 1}\right)$ is a monounsaturated fatty acid. Linoleic (LA, $\mathrm{C}_{18: 2}$ ) and $\alpha$-linolenic (ALA, $\mathrm{C}_{18: 3}$ ) acids are classified as essential polyunsaturated fatty acids. Linoleic acid (LA, $\mathrm{C}_{18: 2}$ ) is a diunsaturated, and $\alpha$-linolenic (ALA, $\mathrm{C}_{18: 3}$ ) - a triunsaturated acid. Palmitic $\left(\mathrm{C}_{16: 0}\right)$ and stearic $\left(\mathrm{C}_{18: 0}\right)$ acids belong to the group of saturated fatty acid (SFA) in oil pressed from seeds. Linoleic acid ( $\mathrm{LA}, \mathrm{C}_{18: 2}$ ) is a precursor of the so called n-6 (omega- 6 ) fatty acids family and $\alpha$-linolenic $\left(\mathrm{C}_{18: 3}\right)$ fatty acids is a precursor to family n-3 (omega-3) [2].

Polish Flax Collection is unique as a very rich source of $\alpha$-linolenic acid. In the study of 16 genotypes of flax, the content of $\alpha$-linolenic acid was from 50.9 (LG-0,1-96 breeding line) to $59.2 \%$ (Bukoz -variety bred by INF\&MP) [3]. The content of linoleic acid was from 9.6 (CVT-LC-36) to $14.5 \%$ (Puławski odporny). The fatty acid ratio n-6/n-3 was from $0.17 / 1$ (Szafir) to $0.28 / 1$ (LG-01-96).

The aim of studies undertaken by the IHAR and the INF\&MP was the evaluation of 9 accessions from Polish Flax Collection according to agricultural (economical) traits: fat content and fatty acids composition in the oil pressed from tested genotypes of flax.

The second goal is to promote the unique Polish Flax Collection Polish collection of flax is unique as very rich source of $\alpha$-linolenic acid. At present, the collection of genus Linum L. comprises 827 genotypes, including 815 accessions of flax
(L. usitatissimum L.) and 12 flax species growing in natural environments [1]. The major part of the collection is stored as seeds, namely genotypes of breeding lines and varieties of fibre and oil flax.

Evaluation of flax collection is important, because polyunsaturated fatty acids of omega- 3 family and omega- 6 family are essential for humans and must be present in the diet [4]. Both acids are so called essential polyunsaturated fatty acids, as human organism cannot synthesize double bonds n-3 (omega-3) and n-6 (omega-6) locations of carbon chains [5].

At present, the prevailing diet in Western countries is characterized with 10 to 30 times higher amounts of consumed omega-6, linoleic fatty acids (LA, $\mathrm{C}_{18.2}$ ) than omega- $3 \alpha$-linolenic fatty acids $\left(\right.$ ALA, $C_{18: 3}$ ) [6]. According to Jelińska the fatty acid ratio $n-6$ to $n-3$ is about 20-30/1 [2]. This causes very grave health consequences, inflammations and lifestyle diseases, also cardiovascular diseases. There is both epidemiological and experimental evidence that dietary polyunsaturated fatty acid (PUFA) modifies also the risk of breast, colon and prostate cancer incidence [2].

The L. usitatissimum species is one of few food sources where higher contents of $\alpha$-linolenic acid or linoleic acid are found in seeds oil. Rudzińska and Wąsowicz [7] list only: Linum usitatissimum, Camelina sativa, fish oil, krill and alga oil and fish meat: tuna, salmon and cod. Among these food sources the $\alpha$-linolenic acid content is the highest in flax. Matławska and Bylka [6] list following food sources of omega-3: flax seed, leafy vegetables, walnut, algae, deep-sea fish or "fatty fish". Meat, vegetable oils, such as corn, sunflower and soybean are rich in omega- 6 fatty acids.

In history, human diet was balanced in terms of n-6 and n-3 fatty acids ratio. Hypothetical fat and fatty acid consumption in human diet in history indicates that industrial societies consume much more saturated fat, trans fat and n- 6 fat, as compared with hunter-gatherer and agricultural societies [2]. However, the consumption of omega- 3 fatty acids has been reduced.

\section{MATERIAL AND METHODS}

The plant material consisted of 9 varieties of oilseed flax (L. usitatissimum L.), collected in the Institute of Natural Fibres (currently INF\&MP) and stored at the National Centre for Plant Genetic Resources in the IHAR - PIB in Radzików. Table 1 shows 
Table 1.

Characterization of linseed varieties from Polish Flax Collection (L. usitatissimum L.)

\begin{tabular}{|c|c|c|c|c|c|c|c|c|}
\hline \multirow{5}{*}{ ACCENAME } & \multirow{5}{*}{ COOLNUMB } & \multirow{5}{*}{ FAT } & \multicolumn{2}{|c|}{ saturated fatty acids } & \multirow{3}{*}{$\begin{array}{c}\text { monounsaturated } \\
\mathrm{C}_{18: 1} \\
\mathrm{n}-9 \\
\end{array}$} & \multicolumn{2}{|c|}{ polyunsaturated } & \multirow{5}{*}{$n-6 / n-3$} \\
\hline & & & $\mathrm{C}_{16: 0}$ & $\mathrm{C}_{18: 0}$ & & $\mathrm{C}_{18: 2}$ & $\mathrm{C}_{18: 3}$ & \\
\hline & & & & & & $n-6$ & $n-3$ & \\
\hline & & & \multirow[t]{2}{*}{ palmitic } & \multirow[t]{2}{*}{ stearic } & oleic & linoleic & $\alpha$-linolenic & \\
\hline & & & & & n-9 & $n-6$ & $n-3$ & \\
\hline $\begin{array}{l}\text { Tabare } \\
\text { INF00111 }\end{array}$ & 165542 & 45.5 & 5.8 & 4.2 & 22.8 & 12.4 & 54.8 & $0.23 / 1$ \\
\hline $\begin{array}{l}\text { Szegedi } 30 \\
\text { INF00427 }\end{array}$ & 165951 & 43.4 & 5.6 & 3.0 & 19.9 & 13.3 & 58.2 & $0.23 / 1$ \\
\hline $\begin{array}{l}\text { Olin } \\
\text { INF00444 }\end{array}$ & 165945 & 42.7 & 6.0 & 3.3 & 24.0 & 14.8 & 51.9 & $0.29 / 1$ \\
\hline $\begin{array}{l}\text { Redwood } 65 \\
\text { INF00523 }\end{array}$ & 166037 & 48.8 & 5.6 & 3.1 & 20.5 & 16.8 & 53.9 & $0.31 / 1$ \\
\hline $\begin{array}{l}\text { Dufferin } \\
\text { INF00540 }\end{array}$ & 166113 & 46.3 & 4.7 & 3.2 & 20.9 & 16.6 & 54.5 & $0.30 / 1$ \\
\hline $\begin{array}{l}\text { AC Mc Duff } \\
\text { INF00648 }\end{array}$ & 166155 & 52.0 & 5.4 & 2.9 & 21.0 & 17.1 & 53.6 & $0.32 / 1$ \\
\hline $\begin{array}{l}\text { Alfonso Inta } \\
\text { INF00683 }\end{array}$ & 166177 & 43.2 & 5.0 & 2.3 & 17.1 & 15.7 & 59.9 & $0.26 / 1$ \\
\hline $\begin{array}{l}\text { Olinette } \\
\text { INF00687 }\end{array}$ & 166180 & 43.4 & 5.6 & 4.0 & 23.0 & 13.3 & 54.1 & $0.25 / 1$ \\
\hline $\begin{array}{l}\text { Royale } \\
\text { INF00689 }\end{array}$ & 166182 & 43.7 & 5.0 & 5.0 & 26.7 & 14.4 & 48.9 & $0.29 / 1$ \\
\hline Min & & 42.7 & 4.7 & 2.3 & 17.1 & 12.4 & 48.9 & $0.23 / 1$ \\
\hline Max & & 52.0 & 6.0 & 5.0 & 26.7 & 17.1 & 59.9 & $0.32 / 1$ \\
\hline
\end{tabular}

FAT, fat content (\%);

content of fatty acids (\%): $\mathrm{C}_{16: 0}$, palmitic acid; $\mathrm{C}_{18: 0}$, stearic acid; $\mathrm{C}_{18: 1}$, oleic acid; $\mathrm{C}_{18: 2}$, linoleic acid; $\mathrm{C}_{18: 3}$, linolenic acid

ACCENAME - name of accessions

COLLNUMB - number of accessions saved at the National Centre for Plant Genetic Resources in the Plant Breeding and Acclimatization Institute, Radzików, Poland

SFA (saturated fatty acids) - palmitic acid + stearic acid

MUFA (monounsaturated fatty acid) - oleic acid

PUFA (polyunsaturated fatty acids) - (linoleic $+\alpha$-linolenic; $n-6+n-3) ; n-6 / n-3$

COLLNUMB - number of accessions of flax stored at the National Centre for Plant Genetic Resources in the IHAR-PIB (tab. 1). The following accessions of flax were investigated: Tabare (INF 00111), Szegedi 30 (INF 00427), Olin (INF 00444), Redwood 65 (INF 00523), Dufferin (INF 00540), AC Mc Duff (INF 00648), Alfonso Inta (INF 00683), Olinette (INF 0687) and Royale (INF 00689).

The article presents results of studies on fat content and fatty acid composition. The following fatty acids was evaluated: $\alpha$-linolenic acid (ALA, $\mathrm{C}_{18:-3}$ ), linoleic acid ( $\mathrm{LA}, \mathrm{C}_{18: 2}$ ), oleic acid $\left(\mathrm{OA}, \mathrm{C}_{18: 1}\right)$, stearic acid $\left(\mathrm{C}_{18: 0}\right)$ and palmitic acid $\left(\mathrm{C}_{16: 0}\right)$. The results are shown as percentage of individual fatty acids content in oil.

Assays determining the content of fat and the composition of fatty acids in linseed oil were performed at the IHAR-PIB Biochemical Laboratory in Poznan. The fat content was determined by infrared analysis (calibration performed on the basis of a seed sample at IHAR-PIB in Poznań) by means of a NIRS 6500 spectrophotometer with a reflection detector within the range of 400-2500 nm. The composition of fatty acids was determined by means of a method proposed by Byczyńska and Krzymański [8], based on gas chromatography of methyl esters of fatty acids contained in linseed oil [9].

For the evaluation of the content of fatty acids as very low, low, medium, high and very high, descriptors for characterization and evaluation were used economic traits from "Descriptor list for flax (L. usitatissimum L.)" edited by Nôžková [10]: fatty acids: 
content of $\alpha$-linolenic acid [\%], linoleic acid [\%], oleic acid [\%], palmitic acid [\%], stearic acid [\%].

Ethical approval: The conducted research is not related to either human or animal use.

\section{RESULTS}

Table 1 presents the characterization of linseed varieties from Polish Flax Collection. The following features of agricultural traits were investigated: fat content (\%) and content of the following fatty acids: $\alpha$-linolenic acid (ALA, $\mathrm{C}_{18: 3}$ ), linoleic acid (LA, $\left.\mathrm{C}_{18: 2}\right)$, oleic acid (OA, $\left.\mathrm{C}_{18: 1}\right)$, stearic acid $\left(\mathrm{C}_{18: 0}\right)$ and palmitic acid $\left(\mathrm{C}_{16: 0}\right)$.

The content of $\alpha$-linolenic acid in evaluated genotypes of flax ranged from 48.9 (Royale) to $59.9 \%$ (Alfonso Inta). The content of linoleic acid in evaluated genotypes of flax ranged from 12.4 (Tabare) to $17.1 \%$ (AC Mc Duff). The content of oleic acid of 9 accession of flax ranged from 17.1 (Alfonso Inta) to $26.7 \%$ (Royale). The content of stearic acid in evaluated genotypes of flax ranged from 2.3 (Alfonso Inta) to $5.0 \%$ (Royale) and the content of palmitic acid ranged from 4.7 (Dufferin) to 6.0\% (Olin). The content of fat ranged from 42.7 (Olin) to $52.0 \%$ (AC Mc Duff). The fatty acid ratio n6/n-3 was from 0.23/1 (Tabare, Szegedi 30) to $0.32 / 1$ (AC Mc Duff).

Tabare variety was characterized with the highest content of $\alpha$-linolenic acid as compared to content of linoleic acid, from 9 accession of flax . Content of $\alpha$-linolenic acid of seeds in Tabare variety was 4.42 times higher than content of linoleic acid - the ratio of $\mathrm{n}-6 / \mathrm{n}-3$ was $0.23 / 1$ (1/4.42) (tab.1).

AC Mc Duff cultivar was characterized by the lowest content of $\alpha$-linolenic acid as compared to content of linoleic acid, from 9 accession of flax) Content of $\alpha$-linolenic acid of seeds in AC Mc Duff variety was 3.13 times higher othan content of linoleic acid - the ratio of $n-6 / n-3$ was $0.32 / 1(1 / 3.13)$.

\section{DISSCUSION}

A very high content of three-unsaturated $\alpha$-linolenic fatty acid is characteristic for flax seeds. The main property of omega-3 family is lowering the risks of cancer, heart diseases, hypertension and dysfunctions of the immune system [11]. The $\alpha$-linolenic acid is present in flaxseed and rapeseed oils, while long chain n-3 fatty acids are found in marine algae and phytoplankton, which synthetize fatty acids in huge amounts and later are found in fish living in cold seas (salmon, tuna, herring, mackerel and sardine) or warm seas [2].

Obiedzińska and Waszkiewicz-Robak [11] presented a list of bioactive compounds characteristic for plant oils. Only flax seed oil and the oil extracted from raspberry seeds have $\alpha$-linolenic acid as a characteristic bioactive compound.

Providing the organism with essential omega- 3 fatty acids in the daily diet is extremely important due to the fact that people cannot synthesize double carbon bonds in n-3 (omega-3) and n-6 (omega-6) position [5]. Another argument for consumption of omega-3 is the fact that in the diet of Western countries 10 to 30 times more omega- 6 (linoleic fatty acid) is consumed than omega-3 fatty acids [6], with causes severe health consequences, inflammations and lifestyle diseases. Łoźna et al. [12] also reports that PUFA $n-6 / n-3$ in the diet in the developed countries reaches from $10 / 1$ to $25 / 1$ and might be even higher.

In the studies by Łoźna et al. [12] the level of $\alpha$-linolenic acid was higher than the content of linoleic acid only in linseed oil with the fatty acid ratio is $n-6 / n-3-0.7 / 1$. In our studies, the fatty acid ratio $\mathrm{n}-6 / \mathrm{n}-3$ ranged from $0.23 / 1$ (1/4.42) (Tabare) to $0.32 / 1$ (1/3.13) (AC Mc Duff). In the 16 evaluated accession of flax, the fatty acid ratio $n-6 / n-3$ ranged from $0.17 / 1$ (Szafir variety) to $0.28 / 1$ (LG-0,196 breeding line). In the study of 84 accessions of flax the content of $\alpha$-linolenic acid ranged from 35.2 to $54 \%$, linoleic acid from 10.8 to $16.1 \%$ in total fat of linseed. The fatty acid ratio $n-6 / n-3$, was $1 / 3.53$ in fibre flax, $1 / 3.35$ in linseed and $1 / 3.26$ in mixed [13]. In another study the fatty acid ratio was also $1 / 3.3$ [14].

In comparison, the value of fatty acid ratio n-6/n-3 in sunflower oil is $335 / 1$, in grapeseed oil $173 / 1$, in maize oil $414 / 1$ and in olive oil $16 / 1$ and the content of $\alpha$-linolenic acid reaches only $0.19 \%$ (sunflower oil), $0.38 \%$ (grapeseed oil), 0.4\% (maize oil), $0.67 \%$ (olive oil) of fat.

Specialists in human nutrition emphasize the importance of the $n-6 / n-3$ ratio in diet, which should be $4-5 / 1$ or even lower [14]. Therefore, one should eat much more food containing three-unsaturated $\alpha$-linolenic omega-3 fatty acid.

In the studies by Obiedzińska et al. [11] the content of $\alpha$-linolenic acid in flaxseed oil is $51.8-60.4 \%$, while in raspberry seed oil it is twice lower as compared with flaxseed oil (29.1-32.4\%). The similar results $52.7 \%$ were obtained by Mińkowski et al. [14]. 
Łoźna [12] with the team found that the richest source of group n-3 was flaxseed (42.9\%) and wild rose oil $(32.1 \%)$. These oils were characterized by the most adequate n- 6 to $n-3$ fatty acids ratio.

In evaluation of 16 genotypes from flax the Szafir (59.1\%) and Bukoz (59.2\%) varieties were characterized with a very high content and 14 flax accession with high content of $\alpha$-linolenic acid [14]. In the present study, Alfonso Inta (59.9\%) and Szegedi $30(58.2 \%)$ had a very high content of $\alpha$-linolenic acid and 7 varieties of flax: Tabare, Olin, Redwood 65, Dufferin, AC Mc Duff, Olinette, Royale had high content from 48.9 (Royale) to 59.9\% (Alfonso Inta) of this acid (tab. 1).

Linoleic acid is consumed in plant oils such as sunflower oil $(63 \%)$, soy oil $(55 \%)$, maize oil (47\%) and safflower seed oil (72\%), not used in Poland [2]. The range of genotypic variations of linoleic acid in 16 accessions of flax ranged from 9.6 to $14.5 \%$ only [3]. It shows that 16 accessions from Polish Flax Collection is characterized with very low content of this acid $(<20.7)$, according to
Nôžková [10]. The content of linoleic acid in linseed oil in the study reported by Mińkowski et al. [14] was also low: $16.2 \%$.

Oleic acid is the main monounsaturated fatty acid in human diet, which is found in all fats and edible oils. Oleic acid is characteristic especially for olive oil and rapeseed oil [2]. The oleic content of cold-pressed flaxseed oil was 15.3\% [12], 19.7\% [ 2 ], $21.2 \%$ [14] and ranged from 19.2 to $26.4 \%$ [3]

When it comes to oleic acid in the study, of 9 flax genotypes, Alfonso Inta was characterized with low content of this acid, Royale with high levels and 7 accessions with medium content of this acid (tab. 2).

Among 9 accessions of flax, 9 descriptors described the content of stearic acid was the same as descriptors described the content of oleic acid (tab. 2). Low content of stearic acid was found in Alfonso Inta $(2.3 \%)$ and high content was found in Royale (5\%), medium content was observed in the following accessions of flax: Tabare, Szegedi 30, Olin, Redwood 65, Dufferin, AC Mc Duff, Olinette (2.9-4.2\%) (tab. 1-2). In the former studies of 16 flax accessions,

Table 2.

Characterization of linseed varieties from Polish Flax Collection (Linum usitatissimum L.) according to Nôžková [9]

\begin{tabular}{|c|c|c|c|c|c|c|c|c|}
\hline \multirow{4}{*}{ ACCENAME } & \multirow{4}{*}{ COOLNUMB } & \multirow{4}{*}{ FAT } & \multicolumn{2}{|c|}{ saturated fatty acids } & \multirow{3}{*}{$\begin{array}{c}\text { monounsaturated } \\
\mathrm{C}_{18: 1} \\
\mathrm{n}-9 \\
\end{array}$} & \multicolumn{2}{|c|}{ polyunsaturated } & \multirow{4}{*}{$n-3 / n-6$} \\
\hline & & & $\mathrm{C}_{16: 0}$ & $\mathrm{C}_{18: 0}$ & & $\mathrm{C}_{18: 2}$ & $\mathrm{C}_{18: 3}$ & \\
\hline & & & & & & $\mathrm{n}-6$ & $\mathrm{n}-3$ & \\
\hline & & & palmitic & stearic & oleic & linoleic & a-linolenic & \\
\hline Tabare INF00111 & 165542 & 45.5 & medium & medium & medium & very low & high & $4.42 / 1$ \\
\hline $\begin{array}{l}\text { Szegedi } 30 \\
\text { INF00427 }\end{array}$ & 165951 & 43.4 & medium & medium & medium & very low & very high & $4.37 / 1$ \\
\hline $\begin{array}{l}\text { Olin } \\
\text { INF00444 }\end{array}$ & 165945 & 42.7 & medium & medium & medium & very low & high & $3.51 / 1$ \\
\hline $\begin{array}{l}\text { Redwood } 65 \\
\text { INF00523 }\end{array}$ & 166037 & 48.8 & medium & medium & medium & very low & high & $3.21 / 1$ \\
\hline $\begin{array}{l}\text { Dufferin } \\
\text { INF00540 }\end{array}$ & 166113 & 46.3 & low & medium & medium & very low & high & $3.28 / 1$ \\
\hline $\begin{array}{l}\text { AC Mc Duff } \\
\text { INF00648 }\end{array}$ & 166155 & 52.0 & medium & medium & medium & very low & high & $3.13 / 1$ \\
\hline $\begin{array}{l}\text { Alfonso Inta } \\
\text { INF00683 }\end{array}$ & 166177 & 43.2 & low & low & low & very low & very high & $3.81 / 1$ \\
\hline $\begin{array}{l}\text { Olinette } \\
\text { INF00687 }\end{array}$ & 166180 & 43.4 & medium & medium & medium & very low & high & $4.07 / 1$ \\
\hline $\begin{array}{l}\text { Royale } \\
\text { INF006899 }\end{array}$ & 166182 & 43.7 & low & high & high & very low & high & $3.39 / 1$ \\
\hline
\end{tabular}

FAT, fat content (\%);

content of fatty acids (\%);

$\mathrm{C}_{16: 0}$, palmitic acid; low (3.9-5.2), medium (5.3-7.2);

$\mathrm{C}_{18: 0}$, stearic acid; low (1.5-2.6), medium (2.7-4.2), high (4.3-5.2);

$\mathrm{C}_{18: 1}^{18: 0}$, oleic acid; low (14.1-19.0), medium (19.1 - 26.4), high (26.5-31.3);

$\mathrm{C}_{18: 2}$, linoleic acid; very low $(<20.7)$;

$\mathrm{C}_{18: 3}, \alpha$-linolenic acid: high (44.7-58.0), very high $(>58.0)$ 
according to Nôžková [10] was as follows: very high -1 accession of flax (6.1\%), high $-4(4.3-4.7 \%)$ and 11 - medium (2.7-4\%).

The content of palmitic acid ranged from 4.7 (Dufferin) to $6.0 \%$ (Olin). According to IFDB the content of palmitic acid was low in 3 genotypes (Dufferin, Alfonso Inta, Royale) and medium in 6 investigated accessions of flax (tab. 2). In the studies of 16 genotypes of flax the amount of palmitic acid was estimated as low for 7 accessions (4.0-5.0\%) and 9 accessions were characterized with medium content of these acid (5.3-5.8\%) [3].

The content of saturated fatty acids was very low and ranged from 7.3 (Alfonso Inta) to 10\% (Tabare, Royale) (tab. 1). In the study of Mińkowski et al. [14] the content of saturated fatty acid was lower than $10 \%(9.8 \%)$.

Semen lini, which at the end of the 20th century was commonly consumed, nowadays is rarely a part of the everyday diet. The Polish word "siemię" is a domesticated Latin term exclusively used for flax [15]. The seeds from accessions of flax can be used for pressing linseed oil. During the increased demand for "natural" food in the group of vegetable fats, consumers search for products other than those produced by extracting oils from seeds with the use of organic solvents or those undergoing subsequent chemical and physical refining processes. [11].

For the production of such oils it is necessary to use seeds with high content of $\alpha$-linolenic acid and low linoleic acid. Polish Flax Collection might be a source of breeding material. Ideally, the seeds should come from organic farming, despite the results of a study conducted in Podlasie region in 2009-2010, that showed decrease in Bukoz variety yields by $1.31-1.75 \mathrm{dt} / \mathrm{ha}$ in comparison with seeds from conventional farming. Bukoz from organic farming was characterized with higher fat content by $1.8-2.1 \%$, as compared with the seeds from conventional farming [16].

However, since 1997, when the first Canadian variety Linola, with very low content of $\alpha$-linolenic acid and very high content of linoleic acid was created [17-20], consumer should have been informed on the composition of polyunsaturated fatty acids with clear information on triunsaturated $\alpha$-linolenic acid and diunsaturated linoleic acid. Low-linolenic flaxseed oil contains about $3 \%$ of omega- 3 and $70 \%$ of omega- 6 , what represents the $n-6 / n-3$ ratio of $23 / 1$ [12].

\section{CONCLUSIONS}

1. The seed of flax (L. usitatissimum L.) of accessions from Polish Flax Collection is a very rich sources of $\alpha$-linolenic acid (ALA, $\mathrm{C}_{18: 3}$ ).
2. The content of $\alpha$-linolenic acid (ALA, $\mathrm{C}_{18: 3}$ ) in evaluated 9 genotypes of flax ranged from 48.9 (Royale) to $59.9 \%$ (Alfonso Inta).

3. The content of linoleic acid ( $L A, \mathrm{C}_{18: 2}$ ) in evaluated 9 genotypes of flax ranged from 12.4 (Tabare) to $17.1 \%$ (AC Mc Duff).

4. The content of oleic acid $\left(\mathrm{OA}, \mathrm{C}_{18: 0}\right)$ in evaluated 9 genotypes of flax ranged from 17.1 (Alfonso Inta) to $26.7 \%$ (Royale).

5. The content of stearic acid in evaluated genotypes of flax ranged from 2.3 (Alfonso Inta) to 5.0\% (Royale) and the content of palmitic acid ranged from 4.7 (Dufferin) to 6.0\% (Olin). The content of saturated fatty acids was very low, ranged from 7.3 (Alfonso Inta) to $10 \%$ (Tabare).

6. The content of fat ranged from 42.7 (Olin) to $52 \%$ (AC Mc Duff).

7. The fatty acid ratio $n-6 / n-3$ ranged from $0.23 / 1$ (1/4.42) (Tabare) to 0.32/1 ( $1 / 3.13$ ) (AC Mc Duff).

8. The content of $\alpha$-linolenic acid of 3 accessions of flax (Tabare, Szegedi 30, Olinette) was most than 4 times higher (tab. 2) than the content of linoleic acid. The content of $\alpha$-linolenic acid of 6 accessions of flax (Alfonso Inta, Olin, Royale, Dufferin, Redwood 65, AC Mc Duff) was most than 3 times higher than content of linoleic acid.

Conflict of interest: Authors declare no conflict of interest.

\section{REFERENCES}

1. Silska G, Praczyk M. Deskryptory charakterystyki i waloryzacji Międzynarodowej Bazy Danych Lnu. Biul Inst Hod Rośl 2013; 268:161-171.

2. Jelińska M. Kwasy tłuszczowe - czynniki modyfikujące procesy nowotworowe. Biul Wydz Farm AMW 2005;1:1-9.

3. Silska G, Praczyk M. Ocena obiektów lnu oleistego (Linum usitatissimum L.). Rośliny Oleiste Oilseed Crops 2012; 33(1):127-138.

4. Schneider Z. Polyunsaturated fatty acids in the diet - how much is too much? In: Proceedings of the Hemp, Flax and Other Bast Fibrous Plants - Production, Technology \& Ecology - Symposium; 1998 September 28-30; Poznań, Poland. 1998; 1:90-96.

5. Gawęcki J.Natura chemiczna tłuszczu a jego wartość odżywcza. In: Gawęcki J (ed.). Prawda o tłuszczach. 
$1^{\text {st }}$ ed. Warszawa. Instytut Danone - Fundacja Promocji Zdrowego Żywienia 1997:10-12.

6. Matławska I, Bylka W. Naturalne niezbędne kwasy tłuszczowe w profilaktyce chorób cywilizacyjnych. Herba Pol 2007; 53(2):39-40.

7. Rudzińska M, Wąsowicz E. Niezbędne nienasycone kwasy tłuszczowe. In: Czapski J, Górecka D (eds.). Żywność prozdrowotna - składniki i technologia. $2^{\text {nd }}$ ed. Poznań 2015:219-235.

8. Byczyńska B, Krzymański J. Szybki sposób otrzymywania estrów metylowych kwasów tłuszczowych do analizy metodą chromatografii gazowej. Tłuszcze Jadalne 1969; 13:108-14.

9. Walkowiak M, Silska G, Michalski K, Praczyk M. Characterization of a collection of linseed (Linum usitatissimum L.) with varying fat content and composition of fatty acids in seed oil. In Proceedings of the $31^{\text {st }}$ Polish Conference: Advances in genetics, breeding, technology and analytics of lipids 2016 Feb 11-12; Poznań 2016:71-72.

10. Nôžková J. Descriptor list for flax (Linum usitatissimum L.). $1^{\text {st }}$ ed. Nitra. Slovak University of Agriculture 2011:1-101.

11. Obiedzińska A, Waszkiewicz-Robak B. Oleje tłoczone na zimno jako żywność funkcjonalna. ZNTJ 2012; 1(80):27-44.

12. Łoźna K, Kita A, Styczyńska M, Biernat J. Skład kwasów tłuszczowych olejów zalecanych w profilaktyce chorób cywilizacyjnych. Probl Hig Epidemiol 2012; 93(4):871-875.
13. Silska G. Polska kolekcja lnu - źródłem nasion o terapeutycznym działaniu. 16. Sejmik Zielarski „Zielarstwo i ziołolecznictwo w Polsce i na świecie, 2016 June 17-18; Trzebaw k/ Stęszewa, Poland. Streszczenia, 61. http://pw.ihar.edu.pl/assets/Uploads/AO-22.08-poster-Sejmik-Zielarski2016r.Silska.pdf

14. Mińkowski K, Grześkiewicz S, Jerzewska M. Ocena wartości odżywczej kwasów linolenowych na podstawie składu kwasów tłuszczowych, tokoferoli i steroli. ZNTJ 2011; 2(75):124-135.

15. Ożarowski A, Jaroniewski W. Rośliny lecznicze i ich praktyczne zastosowanie. Warszawa 1987:225-227.

16. Heller K, Wielgusz K. Plonowanie odmiany lnu oleistego Bukoz w gospodarstwach ekologicznych. J Res Appl Agric Engng 2011; 56(3):138-142.

17. Walkowiak M. Zastosowanie hodowli rekombinacyjnej, mutacyjnej oraz androgenezy in vitro w badaniach nad lnem oleistym (Linum usitatissimum L.). Herba Pol 2007; 28:151-157.

18. Gromek M, Banach J, Czarnecka G, Książkiewicz M. Zimnotłoczone oleje: lniany (wysoko- i niskolinolenowy) i rzepakowy. Który wybrać? Herbalism 2015; 1(1):39-45.

19. Pavelek M, Tejklová E. New varieties. Czech J Genet Plant Breed 2007; 43 (4):149-155.

20. Pavelek M, Tejklova E, Bjelkova M. Results of linseed breeding in the Czech Republic. Tagung der Vereinigung der Pflanzenzüchter und Saatgutkaufleute Österreichs 2010:127-120.

\title{
Zasoby genowe lnu (Linum usitatissimum L.) jako bardzo bogate źródło kwasu $\alpha$-linolenowego
}

\author{
GRAŻYNA SILSKA
}

Instytut Włókien Naturalnych i Roślin Zielarskich

Wojska Polskiego 71B

60-630 Poznań

tel.: +48 61 8455871, e-mail: grazyna.silska@iwnirz.pl 


\section{Streszczenie}

Wstęp: Polska kolekcja lnu oleistego i włóknistego jest źródłem genotypów o bardzo wysokiej zawartości kwasu $\alpha$-linolenowego.

Cel: Przedmiotem badań było określenie zawartości oleju tłustego oraz składu kwasów tłuszczowych w wytłoczonym oleju z 9 testowanych obiektów lnu zwyczajnego (Linum usitatissimum L.). Naszym celem jest promocja polskiej kolekcji lnu, której nasiona są unikalne jako jedne z najbogatszych źródeł kwasu $\alpha$-linolenowego.

Metody: Oznaczenia zawartości oleju tłustego i składu kwasów tłuszczowych wykonano w Laboratorium Biochemicznym IHAR-PIB w Poznaniu. Zawartość oleju tłustego oznaczono analizą bliskiej podczerwieni (kalibracja wykonana na bazie prób nasion w IHAR-PIB w Poznaniu) spektrofotometrem NIRS $6500 \mathrm{z}$ detektorem odbicia 400-2500 nm. Skład kwasów tłuszczowych oznaczono metodą opracowaną przez Byczyńską i Krzymańskiego (1969), z wykorzystaniem chromatografii gazowej estrów metylowych kwasów tłuszczowych zawartych w oleju z nasion lnu. Badania obejmowały następujące odmiany lnu zwyczajnego: Tabare (INF00111), Szegedi 30 (INF00427), Olin (INF 00444), Redwood 65 (INF00523), Dufferin (INF00540), AC Mc Duff (INF00648), Alfonso Inta (INF00683), Olinette (INF00687), Royale (INF00689).

Wyniki: Zawartość kwasu $\alpha$-linolenowego (ALA, $\mathrm{C}_{18: 3}$ ) badanych genotypów lnu wynosiła od 48,9 (Royale) do 59,9\% (Alfonso Inta). Zawartość kwasu linolowego (LA, $\mathrm{C}_{18: 2}$ ) badanych genotypów lnu wynosiła od 12,4 (Tabare) do 17,1\% (AC Mc Duff). Zawartość kwasu oleinowego (OA, $\mathrm{C}_{18: 1}$ ) 9 badanych genotypów lnu wynosiła od 17,1 (Alfonso Inta) do 26,7\% (Royale). Zawartość kwasu stearynowego badanych genotypów lnu wynosiła od 2,3 (Alfonso Inta) do 5,0\% ( Royale) i zawartość kwasu palmitynowego wynosiła od 4,7 (Dufferin) do 6,0\% (Olin). Zawartość tłuszczu wynosiła od 42,7 (Olin) do 52,0\% (AC Mc Duff). Stosunek n-6/n-3 wynosił od 0,23/1 (Tabare) do 0,32/1 (AC Mc Duff).

Słowa kluczowe: len, Linum usitatissimum, kwasy thuszczowe, omega-3, nasiona lnu 